\title{
What is the optimal time for return to sports after anterior cruciate ligament reconstruction?
}

\author{
O. Şahap Atik, MD (D) \\ Professor of Orthopedic Surgery, Turkish Joint Diseases Foundation, Ankara, Turkey
}

Ideal conditions for healing are mostly non-existent in one of the most common sports-related injury, the anterior cruciate ligament (ACL) tear. ${ }^{[1]}$ Furthermore, there are still controversies in regards to the optimal management of a torn ACL and the optimal time for return to sports following ACL reconstruction.

At a mean of six months after ACL reconstruction, objective functional recovery of the knee was generally unsatisfactory and this seemed to be a risk factor for recurrent tears. ${ }^{[2]} \mathrm{A}$ systematic review and meta-analysis demonstrates that younger age and return to high level of activity are evident factors leading to recurrent ACL tears. ${ }^{[3]}$ These combined data indicate that nearly one in four young athletic patients who sustain an ACL injury and return to high-risk sports will develop another ACL injury. ${ }^{[3]}$

The ACL reconstruction does not necessarily enable return to preinjury sports participation. By returning to pivoting sports after ACL reconstruction, athletes are also facing high risks of contralateral ACL injuries. Long-term evaluations in risk assessments after ACL reconstruction are important, as a significant number of subsequent ACL injuries occurs after routine follow-up. ${ }^{[4]}$

Strong evidence indicates that younger, more active athletes are at particularly high risk for a

Received: December 15, 2019

Accepted: January 01, 2020

Published online: March 02, 2020

Correspondence: $O$. Şahap Atik, MD. Turkish Joint Diseases Foundation, Mustafa Kemal Mah., Dumlupınar Bul., 274/2, C2 Blok, Ofis 5, 06900 Çankaya, Ankara, Türkiye.

E-mail: satikmd@gmail.com

Doi: 10.5606/ehc.2020.57891

Citation: Atik OŞ. What is the optimal time for return to sports after anterior cruciate ligament reconstruction? Jt Dis Relat Surg 2020:31(1):1. second ACL injury, and this risk is greatest within the first two years following ACL reconstruction. This highlights a considerable debate in the return to sports decision process as to whether an athlete should wait until two years after ACL reconstruction to return to unrestricted sports activity. ${ }^{[5]}$

An optimized criterion-based multifactorial return-to-sports approach based on shared decisionmaking within a biological and psychosocial framework must be carried out. A wide spectrum of sensorimotor and biomechanical outcomes should be assessed comprehensively. ${ }^{[6]}$ In conclusion, we still do not know the optimal time for return to sports following ACL reconstruction.

\section{REFERENCES}

1. Sezgin EA, Atik OŞ. Are orthobiologics the next chapter in clinical orthopedics? A literature review. Eklem Hastalik Cerrahisi 2018;29:110-6.

2. Raoul T, Klouche S, Guerrier B, El-Hariri B, Herman S, Gerometta A, et al. Are athletes able to resume sport at six-month mean follow-up after anterior cruciate ligament reconstruction? Prospective functional and psychological assessment from the French Anterior Cruciate Ligament Study (FAST) cohort. Knee 2019;26:155-64.

3. Wiggins AJ, Grandhi RK, Schneider DK, Stanfield D, Webster KE, Myer GD. Risk of secondary injury in younger athletes after anterior cruciate ligament reconstruction: A systematic review and meta-analysis. Am J Sports Med 2016;44:1861-76.

4. Lindanger L, Strand T, Mølster AO, Solheim E, Inderhaug E. Return to play and long-term participation in pivoting sports after anterior cruciate ligament reconstruction. Am J Sports Med 2019;47:3339-46.

5. Nagelli CV, Hewett TE. Should return to sport be delayed until 2 years after anterior cruciate ligament reconstruction? Biological and Functional Considerations. Sports Med 2017;47:221-32.

6. Dingenen B, Gokeler A. Optimization of the returnto-sport paradigm after anterior cruciate ligament reconstruction: a critical step back to move forward. Sports Med 2017;47:1487-500. 